the fusion of the sand when the dunes were struck by lightning. These are paper-thin tubes $\frac{1}{8} \mathrm{in}$. to one inch in diameter and penetrating downwards to the depth of eight feet or more.

THE Department of Botany has been presented with the remainder of W. Barton's herbarium excepting the genus Rosa. The present consignment is of about 12,000 sheets with carefully mounted and well-arranged plants, the whole in an excellent condition. The herbarium includes that of $\mathrm{H}$. J. Riddelsdell and Mrs. Foord Kelsey. It is chiefly British, but includes some Alpine collections. The 20,000 sheets make an extremely valuable addition to the collections. Mr. N. Douglas Simpson has presented about 500 flowering plants from the AngloEgyptian Sudan. These form a most useful gift as they supplement the collection made by $J$. E. Dandy, assistant keeper in the Department, on his recent expedition. A collection of 750 flowering plants by H. H. Slater from Iceland, Nova Zembla, Kolquiev, has been purchased ; it fills some gaps in the Department's extensive series of northern plants. Seven note-books which formerly belonged to Edward Forster (1765-1849) have been purchased from the Saffron Walden Museum. They contain a good deal of information about the plants he collected, and can now be again associated with his herbarium which has been in the Department of Botany since 1849. Robert Brown purchased it at the sale of Forster's books and herbarium, and it formed the nucleus of the British Herbarium.

\section{Cambridge University Botanic Garden}

Considerable publicity has been given in the Press to the will of the late Mr. R. R. Cory, who was, in his lifetime, a generous benefactor of the Botanic Garden in Cambridge. He bequeathed the residue of his estate to the University for the benefit of the Garden, with the provision that the income from $£ 30,000$ of the residue should be used for certain specific purposes. This has led to the impression that the Garden would now be provided with an adequate income. Prof. A. C. Seward, professor of botany in the University of Cambridge, informs us, however, that "because of annuities created by Mr. Cory's will, the University should not expect any income for the Garden from his estate for many years to come.. This means that the help hitherto given by the 'Friends of the Botanic Garden', by the promoters of the Somerset Employment Fund and by others interested in the Garden will be as urgently needed and as gratefully received as in the past."

\section{Fireball of January 3, 1935}

Mr. A. KIng, 53 Victoria Road, Ashby, Scunthorpe, Lincs, sends us the following particulars of this object: At $9 \mathrm{~h} .24 \frac{1}{2} \mathrm{~m}$. in the evening of January 3 a fireball, which was nearly as bright as the full moon, shot across south-west England. There were about sixty observations, ranging in place from Peterborough to 10 miles south of Falmouth. From the best of these the following path was deduced:
Began, 55 miles high over English Channel, 23 miles south of Christchurch; mean deviation, $3 \cdot 0$ miles. Ended, 20 miles high over $4 \mathrm{~m}$. south-east of Wottonunder-Edge, Glos.; mean deviation, 1.8 miles. Length of visible track, 92 miles; speed, 13 miles per sec. Radiant, $76^{\circ}-15^{\circ}$, altitude, $22 \cdot 6^{\circ}$. The fireball exhibited remarkable colour changes during its flight, and drew out a red tail. A double detona. tion was heard at Dursley; at Crewkerne the object was seen to split into two halves towards the end of the path, which would seem to account, on the assumption that each piece set up its own shockwave, for the Dursley observation. The velocity, allowing for air-resistance, was of the parabolic order. Assuming parabolic speed, the application of the correction for zenith attraction brought the radiantposition to $77^{\circ}-20^{\circ}$ and yielded the orbit : $\iota, 20 \cdot 5^{\circ}$; $\pi, 139 \cdot 2^{\circ} ; \Omega, 102 \cdot 6^{\circ} ; q, 0 \cdot 8865$. The theoretical parabolic speed was $14 \frac{1}{2}$ miles per second.

\section{Bibliography in Entomology}

The annual meeting of the Royal Entomological Society of London was held on January 16. In his presidential address, Dr. S. A. Neave took as his subject the development of bibliographical work relating to entomology. After dealing briefly with the growth of bibliographical compilations on the subject, Dr. Neave described the organisation responsible for the production of the monthly issues of the Review of Applied Entomology. His own very close connexion with the founding and growth of this periodical enabled him to give to his audience an intimate explanation of the manner in which the literature is surveyed and abstracted : the details of editorial duties and the work of preparing the elaborate indexes which are so prominent a feature in each completed volume. This well-known publica. tion enjoys a world-wide circulation, and aims at keeping workers posted, by means of summaries, in the vast literature pertaining to the agricultural, medical and veterinary aspects of entomology.

\section{Vocational Guidance in the United States}

The vocational guidance scheme which has been in operation in Great Britain for twenty-one years was recently reviewed at the request of the Minister of Labour by a committee of the juvenile employment councils. On the other side of the Atlantic also the 'coming of age' of vocational guidance as a function of the State has been recognised, and the very wide implications of the 'new deal' in this regard are discussed by the associate professor of education and sociology in the University of Pittsburgh in an article in School Life of September. It is pointed out that, in the past, vocational guidance has to a large extent been stultified by the gross inequalities in occupational rewards-inequalities which it is one of the purposes of the 'new deal' to reduce. Further, it has been a matter of national pride that everyone has the right to aspire as high as he will, regardless not only of social position and antecedents but also of apparent qualifications of intellect and character, and however obvious it may be to a vocational adviser 